\title{
Adakitic-like magmatism in western Ossa-Morena Zone (Portugal): Geochemical and isotopic constraints of the Pavia pluton
}

\author{
S.M. Lima ${ }^{\text {a,c,* }}$, A.M.R. Neiva ${ }^{\text {a,c }}$, J.M.F. Ramos ${ }^{b}$ \\ a Geosciences Center, University of Coimbra, Largo do Marquês de Pombal, 3000-272 Coimbra, Portugal \\ b LNEG, Rua da Amieira, Apartado 1089, 4466-901, S. Mamede de Infesta, Portugal \\ c Department of Earth Sciences, University of Coimbra, Largo do Marquês de Pombal, 3000-272 Coimbra, Portugal
}

\section{A R T I C L E I N F O}

\section{Article history:}

Received 26 March 2012

Accepted 11 November 2012

Available online 29 November 2012

\section{Keywords:}

Ossa-Morena Zone

Pavia pluton

Adakitic rocks

Geochemistry

$\mathrm{Sr}-\mathrm{Nd}-\mathrm{O}$ isotopic compositions

\begin{abstract}
A B S T R A C T
Granitic rocks are a major component of the Earth's continental crust and occur in a wide variety of tectonic settings. Their chemical and isotopic characterization is crucial to the recognition of the potential sources and mechanisms involved in their generation. In this study, we present the first whole rock chemical and isotopic (Sr-Nd-O) data for the Pavia pluton (328-317 Ma), located near the western border of the Ossa-Morena Zone (Évora Massif, Portugal). Major and trace element geochemistry suggests that the different granitic phases composing this intrusive body (enclaves, granites (s.l.) and crosscutting dikes) represent independent magma pulses and the majority is similar to TTGs and adakites. The little $\mathrm{Sr}-\mathrm{Nd}-\mathrm{O}$ isotopic variation, with $\left({ }^{87} \mathrm{Sr} /{ }^{86} \mathrm{Sr}\right)_{328}=0.70428-0.70560, \varepsilon \mathrm{Nd}_{328}$ ranging between -3.4 and +0.4 and $\delta^{18} \mathrm{O}$ varying from $+5.6 \%$ to $+8.4 \%$ implies an isotopically similar protolith for all phases. The most viable mechanism for the generation of the Pavia pluton adakitic-like magmatism is assimilation-fractional crystallization of a mantlederived magma. This mechanism was also invoked to explain the genesis of other plutons within the Évora Massif but they have a distinct chemistry (typical arc calc-alkaline rocks). The chemical differences between them and the Pavia pluton granitic rocks are interpreted as the result of lower degrees of crustal assimilation and higher degrees of contamination of mantle-derived magmas by the sinking slab (after subduction blocking and subsequent slab break-off).
\end{abstract}

(c) 2012 Elsevier B.V. All rights reserved.

\section{Introduction}

The origin and analogy of Archean TTGs and modern adakites are still the center of passionate debate (e.g. Castillo, 2012; Condie, 2005; Hastie et al., 2010; Hoffman et al., 2011; Martin, 1999; Martin et al., 2005; Moyen, 2009, 2011; Moyen and Martin, 2012; Rapp et al., 2010; Smithies, 2000). Both terms are commonly used not only for the characteristic chemical composition (high-silica and sodic igneous rocks with high $\mathrm{Sr} / \mathrm{Y}$ and $\mathrm{La}_{\mathrm{CN}} / \mathrm{Yb}_{\mathrm{CN}}$ ratios), but also for their petrogenetic connotation. Adakites usually occur in subduction-related environments resulting from partial melting of hot, hydrated and young $(<25$ m.y.) oceanic crust metabasalts (Defant and Drummond, 1990; Martin, 1999; Martin et al., 2005) later modified by interaction with peridotitic mantle wedge (e.g. Lázaro et al., 2011) or melting of mantle peridotite metasomatized by slab-melts (e.g. Mahlburg Kay et al., 1993). The first model is directly associated with subduction and is responsible for the formation of high-silica adakites (HSA), whereas the second model is indirectly related to subduction and is responsible for the formation of

\footnotetext{
* Corresponding author at: Geosciences Center, University of Coimbra, Largo do Marquês de Pombal, 3000-272 Coimbra, Portugal. Tel.: + 351239860521 ; fax: + 351239860501.

E-mail addresses: selmalima252@gmail.com (S.M. Lima), neiva@dct.uc.pt (A.M.R. Neiva), farinha.ramos@ineti.pt (J.M.F. Ramos).
}

low-silica adakites (LSA) (Martin et al., 2005). However, Danyushevsky et al. (2008) are of the opinion that the distinction between the low-silica and high-silica varieties is not straightforward and that the primitive magnesian andesites are parental to evolved adakites, which is consistent with the previous line of thoughts (Yogodzinski and Kekemen, 1998). Adakitic-like melts can also be produced by assimilation and fractional crystallization (AFC) of parental basaltic magmas (e.g. Bourdon et al., 2002; Castillo et al., 1999; Macpherson et al., 2006), partial melting of delaminated lower crust (e.g. Karsli et al., 2010; Wang et al., 2006) or partial melting of thickened lower crust (e.g. Guan et al., 2012; Karsli et al., 2011; Muir et al., 1995; Petford and Atherton, 1996; Xiong et al., 2003; Yu et al., 2012).

The Iberian Massif (IM) corresponds to the southwestern extension of the European Variscan Belt. Based on differences in the Lower Paleozoic sedimentary record, which are interpreted to reflect their relative proximity to the Gondwana margin (Fernández-Suárez et al., 2011), structure, magmatism and metamorphism, the IM is divided into six main units (Fig. 1a). The Ossa-Morena Zone (OMZ; Fig. $1 \mathrm{~b}$ ) is one of these tectonostragraphic divisions and corresponds to a part of a continental magmatic arc (Armorica) accreted to the Iberian Autochthon (outer continental margin of Gondwana) near the West African Craton (Sánchez-García et al., 2008). The time of accretion is still debated. Some authors (e.g. Quesada, 2006; Ribeiro et 